\title{
Supply Chain Management in Hindustan Unilever Limited
}

\author{
Gowtham C.S, G.Madhan, K.Premalatha
}

\begin{abstract}
To rebuilt the modern bread market through the detail investigation of distributors' problems. - To increase the profit share of Modern Foods Industries Limited through efficient distribution channels To know the sales of different $S K U^{\prime} s$ in Hyderabad market segment..To know the study of distributors problems in distributing the bread in this cut throat competition.To increase the sales through identifying the strong and weak segments.

Keywords : Hindustan unilever limited, sales exicutives.
\end{abstract}

\section{INTRODUCTION}

McCarthy's four P's of the marketing mix include product, price, place and promotion. Distribution management deals with 'the place' part of the marketing mix. In the next few chapters, we will discuss one major aspect of the distribution management process, which is the role and relevance of distribution channel in helping the 'place' aspect of marketing mix.[1][2][3][4]

Distribution Management

This element of the marketing feature offers the client with a place, moment and ownership utility. If a customer wants to purchase a tube of toothpaste is created accessible to this customer in a retail store near his residence - thus giving the ' location ' utility if this consumer want to buy this particular pack of toothpaste at $8 \mathrm{pm}$ on a Tuesday, the consumer in a particular ensures that the tube is available at the retail counter at this chosen time of the consumer- thus providing the 'time' utility. When the consumer goes to the retail shop to buy the tube, he can pay for it and take it home whereby he becomes the owner of the tube of the toothpaste and thus the 'possession' utility has also been provided for.[5][6][7]

In this entire exercise, the consumer has had no direct dealing with the company whose brand of toothpaste in his choice. He has only dealt with the retailer close to his home .how the company has made sure that he gets the tube of toothpaste at the shop closest to his home when he wants it , is the role that the distribution management function of the company has played and which will be discussed in the next few chapters.

Even in instances where a customer wishes to purchase a refrigerator or medications or an industrial buyer plans to purchase a engine or a generator, the scenario would be somewhat comparable.[8][9][10]

Revised Manuscript Received on July 22, 2019.

Gowtham Department of Management studies,BharathInstitute of Higher Education and Research,Chennai,India.

G.Madhan, department, Department of Management studies,BharathInstitute of Higher Education and Research,Chennai,India.

K.Premalatha, Department of Management studies,BharathInstitute of Higher Education and Research,Chennai,India.

\subsubsection{Definitions of Distribution Management}

- The executives of the considerable number of exercises which encourages development and co-appointment of free market activity in the making of time and spot utility in merchandise .

- The workmanship and study of deciding prerequisites, procuring them, conveying them lastly keep up them in an operationally prepared condition for their whole lives. [11]

- Broad scope of exercises worried about the effective development of completed items from the finish of the generation line to the buyer and now and again it likewise incorporates the development of crude materials from the wellspring of supply to the start of the creation lineWe read about the job assembling and administration part play in the development of the GDP of any nation. The assembling part can't add to the development without the help of the dispersion frameworks in working to help the assembling area arrive at the merchandise and enterprises to the end client. Like different areas of the economy that have been impacted by globalization and data innovation, dispersion division has likewise experienced a great deal of changes. [12]

In past, organizations embraced numerous circulations related tasks and numerous organizations accepted that appropriation could be best performed by them. This expected them to assemble and keep up an immense deals power. In any case, as the market extended with the populace, organizations began understanding that the immediate circulation to an all-inclusive customer base was unmanageable and furthermore calm costly. Thus they expressed searching for middle people who could carry out this responsibility better. [13]

Today, with the advancement of an incredible system of middle people, there is no requirement for organizations to play out these capacities. The middle people to play out these play out these capacities and convey benefits at lower costs than if the organization were to improve itself.

Intermediaries, as the name implies, are a link between the manufacturers and his customers.

The primary job is to re-distribute the products of a company in a manner that it reaches the ultimate consumer and gets used. Irrespective of whether one is trying to sell consumer products, technical equipment and machinery, paints and varnishes or computer hardware, the role of intermediaries today has become indispensible. It is 
only the degree of 'intermediation' which can vary between industries and group of customers.[14]

Physical distribution also includes the aspects of transportation, storage and inventory management.

\section{II.RESEARCH METHODOLOGY}

Area of the study

The study was mainly concentrated towards to know the role of distributor in the sales.

Research Design

Enlightening Research: Descriptive research incorporates study and reality discoveries enquire of various types including an itemized study by a survey issuing to merchants of MODERN bread. [15]

\section{A.Information Collection}

The investigation depends on the information gathered through essential and auxiliary sources.

\section{B.Essential Data}

An organized poll was intended to gather essential information from merchants through eye to eye poll review.

\section{C.Optional Data}

Optional information was gathered from diaries, magazines, sites and from other significant productions. [16]

\section{D.Testing Design}

The testing configuration mostly comprises of the example taken for the examination alongside the example size, example casing and inspecting strategy. [17]

\section{E.Test Universe}

All clients of and retailers were taken as the example universe.

Sample Size

From the total of 82 distributors in Hyderabad, a sample size of 49 distributors was selected for the purpose of the study.

Sample Unit The sample unit is used by retailers from East, West, North, South and Central Zones.

Sample Frame Distributors were randomly chosen from which participants were chosen based on comfort.[18]

Sampling Method Sampling convenience was used depending on the readiness and accessibility of the distributor

Limitations

The study is subjected to the following limitations:

- The study was mainly concentrated on study of problems facing by the distributors [19]

- The study is limited to role of distributor in distribution.

- Time for the project is roughly 56 days in which information collection, interpretation, evaluation, conclusion and research goals should be justified. The time available was inadequate in collecting the required information; hence the sample size was limited to 49 distributors.[20]

- Distributors were co-operative in answering all questions that strengthen the accuracy of the research.

- The study was limited to Hyderabad territory only.

4.5 As per the market demand are you receiving supply from the factory on time or not?

Table 1: Receiving Supply according to market requirements

$\begin{array}{lll}\text { Market requirements } & \underline{\text { No of respondents }} & \text { Percentage } \\ \underline{\text { Yes }} & \underline{43} & \underline{88} \\ \underline{\text { No }} & \underline{6} & \underline{12} \\ \underline{\text { Total }} & \underline{49} & \underline{100}\end{array}$

Fig 1: Receiving Supply according to market requirements

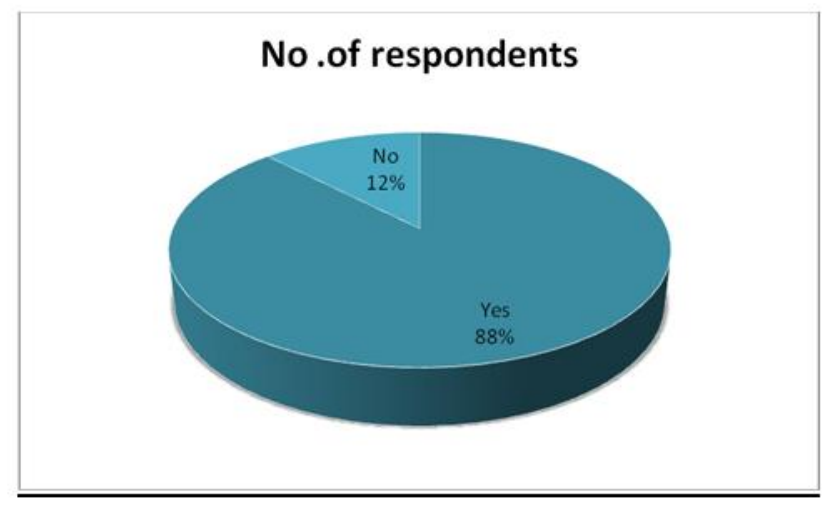

Interpretation: According to the above figure, majority of our distributors receiving stock according to the market requirements. $88 \%$ of distributors getting stock from the factory to meet the customer requirements. And remaining $12 \%$ of the distributors are not receiving the stock.

4.6. Are you satisfied with the supply or not?

\section{Table 2. Distributor Satisfaction}

$\begin{array}{lll}\underline{\text { Market requirements }} & \underline{\text { No of respondents }} & \underline{\text { Percentage }} \\ \underline{\text { Yes }} & \underline{43} & \underline{88} \\ \underline{\text { No }} & \underline{6} & \underline{12} \\ \underline{\text { Total }} & \underline{49} & \underline{100}\end{array}$

Fig:2Distributor Satisfaction

$\begin{array}{lll}\text { Main competitor } & \frac{\text { No .of respondents }}{28} & \text { Percentage } \\ \underline{\text { Britannia }} & \underline{28} & \underline{56} \\ \underline{\text { Spencer }} & \underline{15} & \underline{30} \\ \underline{\text { Golden bite }} & \underline{2} & \underline{5} \\ \underline{\text { Annapuma }} & \underline{1} & \underline{2} \\ \underline{\text { Diamond bite }} & \underline{3} & \underline{7} \\ \underline{\text { Total }} & \underline{49} & \underline{\mathbf{1 0 0}}\end{array}$

Interpretation: According to the above figure, most of our distributors are satisfied with the factory supply. $88 \%$ of the distributors are satisfied with our factory supply irrespective of the bandhs and agitations. This showing our strength in 
the production activity in the trouble periods. And coming to other side of the coin $12 \%$ of the distributors are dissatisfied with the factory supply. The major reason behind this dissatisfaction is improper supply of bread, and improper supply of the Rusk, biscuits \& bun.

According to you, who is the main competitor to our modern bread?

Fig: 3 Competitors to modern bread

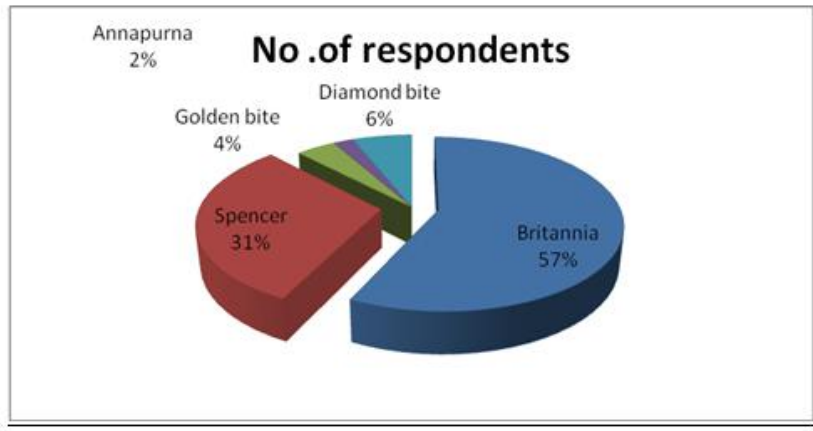

Interpretation: According to the above figure $31 \%$ of the company distributors opinioned that Spencer bread is the second competitor. $6 \%$ of the company distributors' opinioned Diamond bite is main competitor to modern bread. $4 \%$ of the distributors opinioned golden bite bread and $2 \%$ company distributor's opinioned Annapurna bread are the main competitors to modern bread.

How many days our company providing credit facilities? Fig: 4 Credit facilities

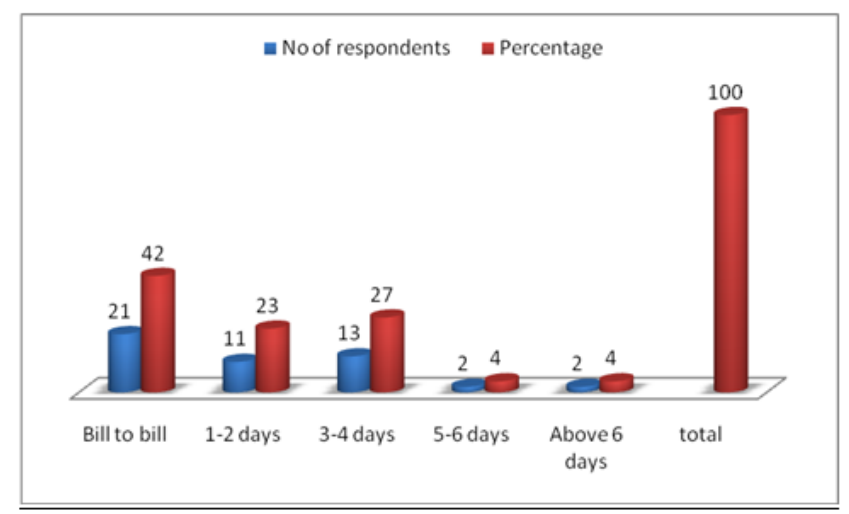

Interpretation: From the above figure the company provided bill to bill credit facilities to $42 \%$ of the distributors and 1-2 days credit facilities to $23 \%$ and $3-4$ days to $27 \%$ of the distributors. Company provided 5-6 days and more than 6 days credit facilities to $8 \%$ of the distributors. Company provided 1 week credit facilities to the distributors who serving more than 10 years and loyal distributors.

4.9. After receiving goods does our sales executives responding your problems on time or not?

Table 3 Responsibilities of sales executives
Table 4.9 Responsibilities of sales executives

\begin{tabular}{|c|c|c|}
\hline $\begin{array}{l}\text { Salesexecutive } \\
\text { response }\end{array}$ & No of respondents & Percentage \\
\hline Excellent & $\underline{13}$ & $\underline{27}$ \\
\hline Very good & $\underline{16}$ & $\underline{32}$ \\
\hline Good & $\underline{14}$ & $\underline{29}$ \\
\hline$\underline{\mathrm{Bad}}$ & $\underline{4}$ & $\underline{8}$ \\
\hline$\underline{\text { Very bad }}$ & $\underline{1}$ & $\underline{2}$ \\
\hline Don't know & $\underline{1}$ & $\underline{2}$ \\
\hline Total & 49 & 100 \\
\hline
\end{tabular}

Figure :5 Responsibilities of sales executives

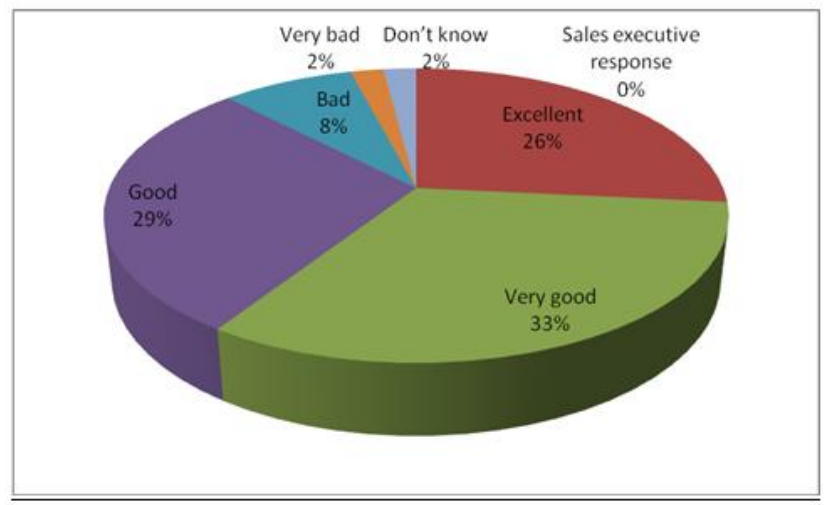

Interpretation: From the above figure, $26 \%$ of the company sales executives provided excellent services to distributors. And $33 \%$ of the sales Executives provided very good services and $29 \%$ of sales executives provided good services. $8 \%$ of the sales executives are provided bad services. $4 \%$ of the sales executives provided very bad services to distributors. [22-25]

\section{III.RESULTS AND DISCUSSION :}

1. The most of respondents are serving to the company since last 5 years.

2. $31 \%$ of distributors are covering north, $16 \%$ south, $25 \%$ east $18 \%$ west and $10 \%$ central zone.

3. 58\% respondents are say Britannia bread is main leading competitor in the company distributed market.20\% respondents say Spencer, $16 \%$ respondents say company bread is leading as a territory leader.

4. The most of people are satisfied and some are unsatisfied with the company supply in relation to the demand.

$5.57 \%$ respondents say Britannia, $31 \%$ of respondents say Spencer, $6 \%$ of respondents says diamond bite, $4 \%$ says golden bite and $2 \%$ of respondents say Annapurna is main competitor to modern bread.[26]

$6.33 \%$ of respondents say excellent and $26 \%$ of respondents say average, $29 \%$ of respondents says good and $8 \%$ of respondents say bad in relation of sales executives responding

to distributors problems.

7. The most of respondents say positively, some of respondents negatively on quality of company products 
8. $67 \%$ of respondents say bad and $33 \%$ of the respondents say good on the aspect of packing and sealing.

9. The most of the respondents say good and some of respondents say bad expiry date.

10 . $69 \%$ of the respondents says no sale, $21 \%$ of respondents say average sale, $6 \%$ says good sale, $6 \%$ of respondents say low sale and $2 \%$ says didn't sell special sweet bread.

11. Most of respondents are not agree on quality compared with bitannia ad spencer bread quality

12. $53 \%$ of respondents say poor and $47 \%$ of respondents say good in packing compared with spencer and Britannia.

13. The most of the respondents say good and some respondents only say bad on prices of products.

14. The most of respondents are ready and say will continue in future if maintain quality, very less respondents say don't know for distributing the goods in futures

15. Newly launched special bread failed in the market due to the reasons [27]

a. No sweetness in the bread.

b. Packing in a special category format.

\section{E.Suggestions:}

- Minimize the deshape products that reduces in stock returns. Customers preferred the proper size of bread packets. Deshape products creating losses to distributors as well as company also. Return stock requires re packing. It cost Extra labor hours in re packing process. Ultimately it was showing the impact on the performance of the company. And Most of the damage to the company sales happened due to this problem of improper shape of bread especially in the milk classic 200 gram and 400 grams. Company must be focus on problem to eradicate the huge loss.[28][29]

- Change the milk bread classic cover 200grams and 400 grams to attract the new customers. All the competitive products are distributed in new packing designs in different color labels to attracting the customers. The company's Major circulated SKU; focus should be maintained to survive in this cut throat competition. [30-31]

- Weak cover used in the packing process makes loss during the distribution from the carry \& forward to retailers. To minimize, company should use thick covers for packing.

- Present market is consumer market. Market covered with full of substitute products from different competitive huts. To sustain in the market, Quality should be improved in order to face the competition.

- Maintain good relations with the distributors. So that they can sell more products

- Loose packing creating problems in handling the products. To overcome this problem packing should be tight and attractive

- Print price tags in big letters to identify the products very easily by the customer. Especially on special sweet bread, Consumers are thinking that it is a high rated product this is the main reason behind the failure of the newly launched bread.

- For launching of any new BRAND from company JULY TO NOVEMBER is right time to introduce new SKU to product group. [32-33]

\section{CONCLUSION}

Present market is consumer market. Market covered with full of substitute products from different competitive huts. To sustain in the market, Quality should be improved in order to face the competition. Maintain good relations with the distributors. So that they can sell more products Loose packing creating problems in handling the products. To overcome this problem packing should be tight and attractive. Print price tags in big letters to identify the products very easily by the customer. Especially on special sweet bread, Consumers are thinking that it is a high rated product .this is the main reason behind the failure of the newly launched bread.

\section{REFERENCES}

[1] BharthVajan R., Ramachandran S.,Psychographic dimensions of training,2016,International Journal of Pharmacy and Technology,V-8,I-4,P-23727-23729

[2] Balakrishnan P., Bharthvajan R.,A study on human resource planning in hospitals in Chennai City,2014,International Journal of Applied Engineering Research,V-9,I-22,P-7503-7507

[3] Priyadarsini P., Bharthvajan R.,Role of emotional intelligence training programme in reducing the stress of the nurses,2014,International Journal of Applied Engineering Research,V-9,I-22,P-7411-7421

[4] Kerinab Beenu G., Bharthvajan R.,Empirical analysis on the cosmetic buying behavior of young women in South India,2014,International Journal of Applied Engineering Research,V-9,I-22,P-7361-7366

[5] Balakrishnan P., Bharthvajan R.,Whistling in the wind,2014,International Journal of Applied Engineering Research,V-9,I-22,P-7586-7593

[6] Krishnan B., Peter M.,Health hazards of Indian Bpo employee-an alarming issue,2014,International Journal of Applied Engineering Research,V-9,I-22,P-7336-7341

[7] Kerinab Beenu G.H., Peter M.,Role of insurance in economic development,2014,International Journal of Applied Engineering Research,V-9,I-22,P-7532-7539

[8] Balakrishnan P., Peter M., Priyadarsini P.,Efficiency of safety measures for wellbeing of employees in manufacturing industry,2014,International Journal of Applied Engineering Research,V-9,I-22,P-7376-7382

[9] Anbarasi M., Praveen Kumar S.,Online sales promotions of herbal products and its effectiveness towards tanisha.com,2019,Indian Journal of Public Health Research and Development,V-10,I-1,P-195-200

[10] Anbarasi M., Praveen Kumar S.,Various online marketing and promotions strategies to improve the validation towards the organic products in the pharmaceutical sectors,2019,Indian Journal of Public Health Research and Development,V-10,I-1,P-263-269

[11] Loganathan R., Praveen Kumar S.,Grievance handling a key factor for solving issues of employees in an organization,2014,International Journal of Applied Engineering Research,V-9,I-22,P-7483-7491

[12]Loganathan R., Praveen Kumar S.,Study on preference of private label brands in super and Hypermarkets,2014,International Journal of Applied Engineering Research,V-9,I-22,P-7327-7335

[13] Smitha M., Praveen Kumar S.,Understanding stress and its managementamong the nurses in Chennai city,2014,International Journal of Applied Engineering Research,V-9,I-22,P-7560-7565

[14]Kerinab Beenu G.H., Praveen Kumar S.,A study on the investment behavior of Chennai investors in mutual fund schemes,2014,International Journal of Applied Engineering Research,V-9,I-22,P-7520-7525

[15] Loganathan R., Praveen Kumar S.,Retention strategies key for organizational productivity,2014,International Journal of Applied Engineering Research,V-9,I-22,P-7443-7447

[16]16) Pavithra J., Ganesan M., Brindha G.,State wise analysis of microfinance sector in India,2016,International Journal of Pharmacy and Technology,V-8,I-4,P-23417-23432

[17] Pavithra J., Ganesan M.,A comparative study on microfinance in India and abroad,2016,International Journal of Applied Business and Economic Research,V-14,I-8,P-5471-5476

[18]Pavithra J., Ganesan M.,A study on awareness and impact of micro-financial schemes,2016,International Journal of Applied Business and Economic Research,V-14,I-8,P-5449-5460

[19] Senthilmurugan P., Pavithra J.,Consumer preference towards organised retailing with reference to Big Bazaar,2014,International Journal of Applied Engineering Research,V-9,I-22,P-7469-7475

[20] Senthilmurugan P., Pavithra J.,Implication of social media marketing in growing healthcare industry,2014,International 
Journal of Applied Engineering Research,V-9,I-22,P-7448-7456

[21] Loganathan R., Pavithra J.,Consumer perception towards private label brand over other brands in super markets and hypermarkets,2014,International Journal of Applied Engineering Research,V-9,I-22,P-7355-7360

[22]Kerinab Beenu G., Pavithra J.,Tradeâ€"off between liquidity and profitability in logistics industry,2014,International Journal of Applied Engineering Research,V-9,I-22,P-7398-7401

[23] Kerinab Beenu G., Pavithra J.,A study on the prospective consumerâ€ TM $_{\mathrm{S}}$ perception towards utility cars in Chennai city,2014,International Journal of Applied Engineering Research,V-9,I-22,P-7526-7531

[24] Pavithra J., Dilli Babu P., Ambuli T.V.,A study on budgetary control at Maruti Service Masters, Chennai,2014,International Journal of Applied Business and Economic Research,V-12,I-2,P-151-161

[25] Pavithra J., Dilli Babu P., Ambuli T.V.,A study on customer satisfaction of retro Garments Pvt Ltd, Chennai,2014,International Journal of Applied Business and Economic Research,V-12,I-2,P-381-391

[26] Kerinab Beenu G.H., Pavithra J., Senthilmurugan P.,A study on the influence of promotional activities for TATA ARIA among consumers in Chennai,2014,International Journal of Applied Engineering Research,V-9,I-22,P-7572-7578

[27] Vijayaragavan S.P.,An investigative expert that's general FBG sensors,International Journal of Mechanical Engineering and Technology,V-8,I-8,PP-1500-1505,Y-2017

[28] Vijayaragavan S.P.,Equalization routing protocol for Wi-Fi sensor strategy,International Journal of Mechanical Engineering and Technology,V-8,I-8,PP-1662-1666,Y-2017

[29] Karthik B., Kiran Kumar T.V.U., Vijayaragavan P., Bharath Kumaran E.,Design of a digital PLL using 0.35 $\hat{\mathrm{I}}^{1 / 4 \mathrm{~m}}$ CMOS technology,Middle East Journal of Scientific Research,V-18,I-12,PP-1803-1806,Y-2013

[30]Kanniga E., Selvaramarathnam K., Sundararajan M.,Kandigital bike operating system,Middle - East Journal of Scientific Research, V

[31] Jasmin M., Vigneshwaran T., Beulah Hemalatha S.,Design of power aware on chip embedded memory based FSM encoding in FPGA,International Journal of Applied Engineering Research,V-10,I-2,PP-4487-4496,Y-2015

[32]Jasmin M.,Optimization techniques for low power VLSI circuits,Middle East Journal of Scientific Research,V-20,I-9,PP-1082-1087,Y-2014

[33] Jasmin M., Vigneswaran T.,Fuzzy controller for error control of on - Chip communication,2017 International Conference on Algorithms, Methodology, Models and Applications in Emerging Technologies, ICAMMAET 2017,V-2017-January,I-,PP-1-5,Y-2017

\section{AUTHORS PROFILE}

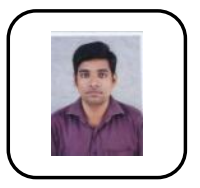

Gowtham C.S,Assistant Professor,. Department of Management studies,Bharath Institute of Higher Education and Research, Chennai, India

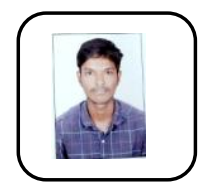

Madhan.K Student,. Department of Management studies,Bharath Institute of Higher Education and Research, Chennai, India

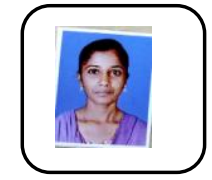

K.Premalatha.Student,. Department of Management studies,Bharath Institute of Higher Education and Research, Chennai, India 